\title{
Social Flux and Disaster Management: An Essay on the Construction of an Indonesian Model for Disaster Management and Reconstruction
}

\section{$\operatorname{AUTHOR}(\mathrm{S})$ :}

Nishi, Yoshimi; Yamamoto, Hiroyuki

\section{CITATION:}

Nishi, Yoshimi ... [et al]. Social Flux and Disaster Management: An Essay on the Construction of an Indonesian Model for Disaster Management and Reconstruction. Journal of Disaster Research 2012, 7(1): 65-74

\section{ISSUE DATE:}

2012

URL:

http://hdl.handle.net/2433/228304

\section{RIGHT:}

(C) 2012 Fuji Technology Press Co, . Ltd.; この論文は出版社版でありま せん。引用の際には出版社版をご確認ご利用ください。; This is not the published version. Please cite only the published version. 


\title{
Social Flux and Disaster Management: An Essay on the Construction of an Indonesian Model for Disaster Management and Reconstruction
}

\author{
Yoshimi Nishi and Hiroyuki Yamamoto \\ Associate Professor, Center for Integrated Area Studies, Kyoto University \\ Sakyo-ku, Shimoadachimachi 46, Kyoto-shi, Kyoto 606-8501, Japan \\ E-mail: ynishi@cias.kyoto-u.ac.jp \\ [Received August 6, 2011; accepted December 26, 2011]
}

\begin{abstract}
To understand the socially rooted measures in disaster management and reconstruction, we studied Indonesia as a model from the perspective of social flux, by incorporating the latest knowledge in this field. Characteristically, in Indonesian society, people move so frequently that it is difficult for information or knowledge to accumulate; their living and occupational forms are constantly in flux. Because of these characteristics, supporters and local residents of Indonesia have devised a variety of measures for effective disaster management, humanitarian assistance, and reconstruction. However, such measures have often not been positively evaluated - they have been viewed as an immature response of Indonesian society. In this paper, we have positively reviewed the various measures taken in response to the Indian Ocean tsunami of 2004, the Java earthquake of 2006, and the West Sumatra Earthquake of 2009 in order to construct an Indonesian model of disaster management and reconstruction from the perspective of social flux. We hope the proposed model will also prove effective in many other parts of the world.
\end{abstract}

Keywords: information, technology transfer, emergency humanitarian assistance, area studies, social flux

\section{Preface}

\subsection{Social Aspects of Disaster Management and Reconstruction}

Disasters have often been addressed in the context of prevention and reconstruction. In post - World War II Japan, people first paid attention to the reconstruction of the war-devastated country. Then, pollution problems were addressed. Currently, we have started focusing on disasters and security problems, which include terrorism. People are also concerned about infectious diseases such as severe acute respiratory syndrome (SARS) and avian flu. ${ }^{1}$

1. For the history of disaster management studies in Japan, refer to Reference [1].
As far as natural disasters are concerned, people's interest is shifting from "disaster prevention" to "disaster mitigation" in the hope of reducing disasters as much as possible. People are beginning to realize that completely preventing physical damage might not be feasible because advances in quake-resistant engineering will not make buildings entirely earthquake proof. Social aspect plays an important role in disaster mitigation. Therefore, we need to obtain resources from other disciplines such as human and social sciences. Conventional disaster management studies in Japan have been focusing on support from public organizations and residents' groups. ${ }^{2}$ Nowadays, non-experts in disaster management, including volunteers, participate in operations at disaster sites, and they are expected to play important roles. More studies are needed to effectively deal with the reconstruction of devastated areas and the rehabilitation of victims, keeping in mind the diversity of affected societies and the overall impact on society. ${ }^{3}$

Area studies in Japan have rarely paid attention to disaster management. However, in the wake of the Indian Ocean tsunami in 2004, more attention is being paid to the process of disaster management in the affected areas around the Indian Ocean. Studies are also being conducted in the areas of disaster management and humanitarian assistance. ${ }^{4}$ This paper is based on the accumulated studies on disasters. We discuss how information and technology should be conveyed in a society in which international relief agencies play important roles in disaster management, humanitarian support, and reconstruction. Here, disaster science, information, and technology are introduced by external agencies. This paper addresses specific cases in Indonesia in the hope that these cases will serve as a model for other countries and regions.

\footnotetext{
2. Refer to Reference [2] for disaster management in modern Japan and to Reference [3] for disaster management in pre-modern Japan.

3. Some examples of such studies include References [4,5]. Reference [6] attempts to regrasp the conventional concepts of disaster management based on actual experiences at disaster sites.

4. Reference [7] presents the on-site investigations by area studies researchers of the Indian Ocean tsunami in 2004. Reference [8] is the only work that deals with disaster damage and reconstruction in the local context in area studies in Japan before 2004. For grasping disaster management from the anthropological perspective, refer to Reference [9].
} 


\subsection{Information and Technology in Disaster Man- agement and Reconstruction}

We might think that if correct information and technology were given to people, they would respond appropriately in disaster management, humanitarian assistance, and reconstruction. However, people sometimes do not respond appropriately even when correct information and required technology are provided. ${ }^{5}$

One school of thought premised that universal information and technology is always available. They believe that the above-mentioned inappropriate responses were caused because information and technology were not always introduced in their original forms to individuals. Such problems could be resolved by developing social infrastructures to facilitate people's access to correct information and technology. ${ }^{6}$

Another school of thought asserts that information and technology are different realities to different people; therefore, it is important to "translate" information and technology to suit individual situations. The role of intermediaries who understand universal information and technology as well as local contexts is important for such "translations."

Local counterparts could act as intermediaries, as seen in the field of developmental assistance and technology transfer. ${ }^{7}$ However, local counterparts are often obliged to accept a subordinate position to external supporters and engineers who provide information and technology to the area. It is essential, therefore, to review the role of intermediaries in developmental assistance and technology transfer and define their roles more positively. ${ }^{8}$ Local counterparts, who understand both the universal and the local contexts, can "translate" information and technology in forms appropriate to the local situations.

This paper discusses the various aspects of "translation" of information and technology in disaster management, humanitarian assistance, and reconstruction in Indonesia. It is based on two features of Indonesian society pointed out in the area studies: high social flux ${ }^{9}$ and large socio-cultural diversity.

The concept of social flux has not been studied enough in disaster management and humanitarian assistance in In-

5. Japan Meteorological Agency issued large-scale tsunami warnings to Aomori, Iwate, and Miyagi Prefectures. It also issued similar tsunami warnings to other regions in Japan where local governments issued evacuation directives or calls to local coastal residents when the Chilean earthquake and tsunami occurred in February 2010. According to the Fire and Disaster Management Agency of Ministry of Internal Affairs and Communications, the evacuation rate of local residents was $6.5 \%$ in the regions where evacuation directives were issued and $2.6 \%$ in the regions where evacuation calls were issued.

6. Developing social infrastructures will help avoiding circulation of rumors by providing authorized information. For information and rumors, refer to Reference [10].

7. Reference [11] gives the general picture of mainstreaming of participatory development processes in the field of developmental assistance.

8. Reference [12] attempts to perceive the processes of localization by which universal values as represented by the modern world system are accepted by local communities. Reference [13] describes the relationships between assistance givers and assistance receivers where assistance receivers consciously interpret the intentions of assistance givers.

9. High social flux, described in detail in the following section, not only refers to vertical and horizontal movements of people between different social levels but also to the fact that a large percentage of society members have flexibility in the forms of residences, occupations, or communities. donesia. We first describe the various issues involved in the conventional ways of disaster management and humanitarian assistance. In particular, we discuss the issues involved in the distribution of aid and the sharing of knowledge for disaster management. Then, we discuss how disaster management and humanitarian assistance should be pursued by taking the concept of social flux into consideration. ${ }^{10}$

\subsection{Social Flux in Southeast Asia}

A high social flux generally indicates frequent movements of people or frequent changes in the membership of a society and fluidity in the roles played by its members. Southeast Asian societies - particularly Indonesia are known as societies with high social flux.

In Southeast Asia, which is traditionally characterized by small populations, political power has been linked to the control of access to goods or information. ${ }^{11}$ In pre-modern Southeast Asia, rivers were the major transportation routes. ${ }^{12}$ Therefore, those who controlled the ports seized political power. ${ }^{13}$ Port polities could not completely control the inland areas that yielded commodities, such as rice, gold, and forest products. There were vast unexplored inland areas. When people became uncomfortable with the rulers of port polities, they moved to other areas. It was geopolitically too difficult to tightly control people's movements and prevent them from moving out to other areas in port polities. ${ }^{14}$

It is a traditional practice in Southeast Asia for adult men to leave their birthplaces and to live in other lands. ${ }^{15}$ The Minangkabau people in West Sumatra, Indonesia, are well known for their practice of merantau (i.e., going abroad or away from one's birthplace). In the Minangkabau society, the women own and inherit real estate, and men leave their birthplaces to live in other areas. ${ }^{16} \mathrm{In}$ the 1970s, the Indonesian government launched a national policy of transmigration, which aimed to move the labor force from the crowded Java Island to the less crowded Sumatra Island and other Indonesian islands. ${ }^{17}$ Provincial demographic statistics show that almost every local city has a mixture of ethnic groups from other areas in Indonesia. ${ }^{18}$ The range of merantau is not limited to the

10. For review on disaster management and humanitarian assistance in Indonesia from the viewpoint of area studies, refer to "Disasters and Area Studies" in Issue No.2 of Volume 11 of the Journal "Area Studies" (Showado, 2011).

11. For less-populated societies in Southeast Asia, refer to Reference [14].

12. Refer to Reference [15]. Such political powers include Ayutthaya Kingdom in Thailand and Aceh Kingdom in Sumatra.

13. For port polities, refer to References [16] and [17].

14. For the difficulties the Western powers experienced with border control in the colonization of the Southeast Asia, refer to Reference [18].

15. Such practices are seen in many regions in Sumatra. Among such regions, the West Sumatra province is traditionally known as the area where men move out.

16. The merantau practice of the Minangkabau people is briefly summarized in References [19] and [20]

17. Immigration policies date back to the Dutch colonial period. For the overview and social impacts of the immigration policies including the Dutch colonial period, refer to References [21,22].

18. For example, the ratios of the Javanese in the provincial populations of Sumatra Island are as follows: $15.9 \%$ in Aceh; $32.6 \%$ in North Sumatra; $4 \%$ in West Sumatra; $25.1 \%$ in Riau; $27.6 \%$ in Jambi; $27.0 \%$ in South Sumatra; $22.3 \%$ in Bengkulu; $61.9 \%$ in Lampung; and $5.8 \%$ in Bangka Belitung [22] 
domestic areas of Indonesia because an increasing number of laborers are going abroad to work as housemaids or construction workers.

The extension and reconstruction of buildings is very popular, and owners prefer to do this work themselves rather than leave it to professional contractors. ${ }^{19}$ Such buildings often do not have quake-resistant designs. ${ }^{20}$

In Indonesia, people often change their form of accommodation as well as occupation; they prefer not to stay in the same job for too long.

In societies having high social flux, knowledge or experiences are not easily shared and accumulated by all the members of the society. This is not because there is limited access to correct information but because every member of the society has a different reality. We reviewed the processes for disaster management, humanitarian assistance, and reconstruction in Indonesia based on the above assumptions. $^{21}$

\section{Role of Posko in Emergency Humanitarian Assistance}

In communities where knowledge and experiences are not collected from the grassroots level and not passed down from the top, each unit of society sets up posts to share information with other units. Such posts are called poskos in Indonesia.

In this section, we report our investigation results including the findings of the field surveys in Aceh. To investigate the reconstruction process, we visited Banda Aceh City over many months: February, August, and December (2005); September and December (2006); February, September, and December (2007); January, August, and December (2008); February, August, and October (2009); and August (2011). We interviewed local residents and the staff of government organizations and NGOs.

\subsection{Posko}

In the wake of large-scale natural disasters, relief organizations tried to ensure the efficient delivery of limited relief goods without any overlapping. Governmental and international organizations provided assistance by dividing the affected areas sectorwise into distinct administrative units.

Disaster victims are evacuated to places within and beyond the administrative boundaries, whereas relief and rehabilitation assistance is given along administrative boundaries. The disaster victims who are evacuated outside their original residences might not be able to receive

19. For extension or reconstruction of buildings in Indonesia, refer to Reference [24].

20. A hotel that had been extended many times, without adhering to official safety regulations, collapsed. The death toll was approximately 300 , which is $30 \%$ of the total number of victims in the West Sumatra earthquake in 2009.

21. The perspective of social flux also presents a new approach to the studies on regional conflicts. Based on the perspective of social flux, for example, Aceh conflicts can be taken as Acehnese people's responses to the restrictions imposed on them to limit social flux in the region. Refer to References [25] and [26]. assistance. In societies with high social flux, therefore, there needs to be some arrangements to link the supporters and the disaster victims who have been evacuated to places outside their original residences.

The structure called posko played an important role in the Aceh province of Indonesia, in the wake of the 2004 Indian Ocean tsunami. ${ }^{22}$ Posko is an abbreviation for pos kordinasi, which means "coordination post" in Indonesian. These are voluntarily organized communication posts to respond to events in Indonesia. A posko can be organized by any organization: government, private, domestic, or foreign. It is an ad-hoc organization for a particular purpose and is shut down after it fulfills its purpose.

Each posko is unique. The lines of command among poskos are not fixed, and cooperation and relationships between poskos are flexible. Hence, the posko of a district government is not always superior to that of the village offices.

When an assistance giver provides goods and information to a posko, that particular posko serves as a coordinator that provides goods and information to other poskos. In this way, poskos establish flexible relationships with one another, depending on the flow of goods and information. In this way, poskos ensure that assistance is provided to disaster victims who move to places beyond administrative boundaries.

\subsection{Administration Villages and NGO Villages}

The case of the Deah Glumpang village in Banda Aceh city provides us an example of posko activities. The Deah Glumpang village is a residential area located near the coast. The percentage of residents engaged in fishery, family-operated business, and the aquaculture industry were approximately $40 \%, 30 \%$, and $10 \%$ respectively. Some of the remaining villagers were public servants. These statistics are from before the tsunami attack.

Approximately 1,000 out of the 1,300 residents, including the village headman, were killed in the tsunami in 2004. The residents set up a posko outside the village because there was tremendous confusion in the Deah Glumpang village immediately after the tsunami. For distributing relief goods, students of the State Institute of Islamic Studies in Aceh led the task of collecting data on the disaster victims of the village. In February 2005, surviving residents gathered in the village posko to elect a new village headman and reported the election results to the competent district head.

After almost all the bodies of the victims were recovered, the village posko was established in March 2005. The former headman's son, who worked at the Public Works Department, was stationed in the posko. When government officials or assisting organizations visited the posko, he showed them the list of surviving residents to

22. For detailed information on posko in Aceh, refer Reference [27].

23. Posko Satkorlak Penanggulangan Bencana Alam NAD (Coordination Post for Disaster Management in the Aceh province) is the highest post to respond to disasters in the Aceh Provincial Government. Note that it is also a posko as the word posko is included in its official name. 
receive relief goods. Then, the evacuated villagers were contacted on their mobile phones, and the relief goods were distributed to them.

There was no building, electricity, gas, or water supply in the village when the posko was set up; yet, the villagers decided to set up the posko in the village. The Deah Glumpang village is located on the coast in which all buildings were swept away by the tsunami. Therefore, it was visited by many people who came to the tsunamiaffected sites in Banda Aceh. The village was also visited by assisting organizations, which gave relief goods. Most importantly, the posko was set up to receive assistance from the government because governmental assistance was provided based only on administrative boundaries.

The government follows specific rules for providing assistance, whereas international organizations and NGOs follow their own methodology for distributing relief goods. Poskos were set up to coordinate assistance from both assistance givers. Thus, tent communities or evacuation centers with poskos functioned as "villages" to receive assistance from NGOs, though the "villages" were not actually "administrative villages." Disaster victims registered themselves in administrative villages and NGO villages, and the poskos linked them together.

\subsection{Mock Tents and "Three-day Rule" in Tent Vil- lages}

Residents of the Deah Glumpang village were evacuated to the Mata Ie tent village. Mata Ie is located inland in the suburbs of Banda Aceh and belongs to the Aceh Besar district. Some seven hundred tents were pitched on the premises of the Indonesian Republic Television (TVRI) situated on a hilltop. Here, disaster victims of the Deah Glumpang village lived in tents together with evacuees from other districts.

In the tent village, ration coupons were issued to each household to avoid possible confusion in the distribution of relief goods. Three associations coordinated the work of the distribution system with the Students of Nature Lovers (Mapala) in Aceh taking the lead. It was headed by a lecturer of the Economics Department of Syiah Kuala University, an ex-Mapala member. In the second week after the tsunami, the residents of the tent village were divided into blocks ranging from $A$ to $E$. The residents were registered in these blocks by 25 students who conducted a survey on them. By August 2005, the approximate numbers registered were as follows:

(i) 150 households (i.e., 700 residents) in Block A;

(ii) 125 households (i.e., 600 residents) in Block B;

(iii) 270 households (i.e., 1,200 residents) in Block C;

(iv) 140 households (i.e., 520 residents) in Block D; and

(v) 50 households (i.e., 230 residents) in Block E.

Residents of each block elected their own heads called keucik or village headman in Acehnese language.
Relief goods from NGOs were delivered to the Mata Ie tent village; then, they were distributed to the residents through blocks. The residents of the Mata Ie tent village also received relief goods from the government through poskos set up in their original villages. Thus, by using poskos, the residents of the tent village could receive relief goods from both the government and NGOs.

Registering oneself in the tent village was considered a privilege by many persons. An interesting case of a mock tent will highlight this understanding. The Mata Ie tent village was well known among NGOs for its nicely built tents. Some had even put up tents that looked almost like luxury homes with lush gardens. Trees were planted in planters made of used tires; steps were built in front of the tent using ground soil; and waste pipes were transformed into handrails. It looked as if a beautiful tent contest was taking place in the Mata Ie tent village.

Interestingly, not many of the luxurious tents were inhabited because they were not suitably constructed or furnished. Owners of these tents found them too hot at night, and many chose to stay outside the tent village in the homes of their relatives. They used to visit the tent village during the day to do gardening and demonstrate their presence in the tent village; otherwise, they feared that their registration as residents of the tent villages would be cancelled and they would be disqualified as recipients of relief goods.

The Mata Ie tent village later set up a "three-day rule," according to which the residents of the tent village were allowed to stay one or two nights outside the village. However, if they stayed three nights in a row, their registration was cancelled, and they were deprived of the right to receive rations. This rule showed that the residents of the Mata Ie tent village considered it a privilege to receive relief goods; therefore, they returned to their tents every three days to retain the privilege.

\subsection{Disaster Victims in Motion}

The post-tsunami Acehnese society showed that disaster victims who were evacuated at various places maintained contact with one another. They moved out if they found a better place and made efforts to settle down rather than stay outside temporarily and return to the tent.

Besides the disaster victims, unaffected people also moved to better places in the aftermath of a disaster. People from surrounding regions flocked to post-tsunami Banda Aceh in the hope of obtaining more business opportunities during reconstruction. They moved into vacancies in the tents or temporary housings after disaster victims had left the place. As a result, disaster victims and unaffected people from other regions mingled in the tent villages and temporary housings. It soon became difficult for international assistance givers to distinguish the disaster victims from the unaffected people. 


\section{Technology Transfer in High-Flux Societies}

In societies with high social flux or societies with high turnover of population, it is difficult to accumulate knowledge and technology in a social circle. For example, attendance at workshops and seminars in Indonesia often drops toward the end of the sessions. People have been very ingenuous in accumulating knowledge and technology in social circles in high-flux societies.

Such ingenuities in transferring technology are seen in the activities of Japanese humanitarian assistance organizations, which operated after the West Sumatra (Padang) earthquake in September 2009. There are two possible approaches to the effective transfer of technology: by employing international standards and by transferring the culturally-based values and thought processes. Both international standards and Japanese values and ways of thought are strange to the Indonesian people, and the local volunteers tried to "translate" the approaches into forms acceptable to the local community.

The data described below are based on our field research on seven humanitarian assistance organizations in Padang city and Padang Pariaman district, West Sumatra, in March 2010. ${ }^{24}$

The West Sumatra earthquake in 2009 caused over 1,000 deaths. The Indonesian Government declared the earthquake as a national disaster and led the emergency relief operations. Japan dispatched a search and rescue team and an emergency medical support team. Humanitarian assistance teams under the Japan Platform (JPF) also provided assistance. ${ }^{25}$

\subsection{Socio-Cultural Background of West Sumatra}

\subsubsection{Culture of Leaving Birthplaces and Absence of Architectural Experts}

The minangkabau people who form a majority in the West Sumatra province are a matrilineal society. Lands and houses are owned by women, and daughters inherit from their mothers. A married couple lives in the wife's house. The husband-father role is not considered crucial for men; instead, working away from home is considered important.

In the traditional Minangkabau society, women used to live in large and durable houses. Men used to live in humble huts in rice fields or mountains. In the 19th century, after the Netherlands established control over West Sumatra, its population started growing, and a monetary economy was introduced. These social transformations changed the style of accommodation from traditional, large, durable houses for joint families to modern, small, less-durable houses for nuclear families.

The above-mentioned characteristics of the Minangkabau society are also evident in the earthquake-affected areas of West Sumatra. Most young men work away from home, but as they get older, they often come back to West Sumatra to build houses. Nevertheless, it is not so easy to

24. For more details, refer to References [28, 29], and [30]. 25. Refer to Reference [31]. find stable occupations in West Sumatra, which has minimum natural resources. Therefore, these men are sometimes employed to farm on other people's fields or fish using borrowed boats. Some men were employed for construction work in villages; however, they were regarded as temporary construction workers rather than architectural experts because they lacked adequate specialized technical skills.

\subsubsection{Abundant and Uncontrolled Water}

In the Padang Pariaman district, a number of rivers flow in parallel from the mountainous midland to the coastal area on the west coast, and villages are formed on the ridge paths between the rivers. In the rainy season from September to December, heavy rains cause landslides that obstruct vehicular traffic on the ridges. These landslides also block the paths connecting villages with one other. Sometimes, entire villages are engulfed by landslides.

Failure to harvest the abundant water supply forces villagers to build their houses on the ridges where there is at least some water availability. Water scarcity causes villagers to collect rainwater in water storage tanks, which is then used for basic household activities such as cooking, washing, and bathing. During the dry season, villagers need to walk several kilometers to nearby valleys to collect water for domestic use.

Water scarcity is closely linked to hygiene problems. In every household, cooking, washing, and bathing are done in a narrow space next to a water storage tank at the back of the house. In the dry season, all these activities have to be performed with a limited amount of water. In the West Sumatra earthquake, the houses did not appear to be heavily damaged, but the water storage tanks were destroyed because of which potable water was not available in many houses.

\subsection{Japanese Humanitarian Assistance Organiza- tions in West Sumatra}

Japanese assistance organizations focused their support activities on securing hygienic water and building technologies as seen below. ${ }^{26}$

\subsubsection{Assistance Organization A}

Assistance Organization A donated water supply facilities to elementary and secondary schools. The water supply facilities, installed in collaboration with local residents, helped store the water piped from water sources located at the bottom of cliffs several kilometers away. After installing water storage facilities, the Japanese staff of the organization endeavored to inculcate accommodating attitudes in the local staff and residents.

It is generally observed in development assistance projects that local people do not fully understand the developer's ideas. This results in friction between supporters and local residents causing the interruption of support

\footnotetext{
26. The discussion in the following section is based on the investigation reports conducted by the writers of this paper. Refer to References [29, 30], and [31].
} 
activities. If support activities are interrupted, humanitarian assistance organizations are unable to report their developmental activities to their donors. To avoid such problems, many assistance organizations give in to the demands of local residents.

However, Assistance Organization A dared to take a sufficiently long time to win the support of the local staff and residents without fearing project interruptions. The Japanese staff had rich experience in providing assistance to projects in Indonesia and other Asian countries. These acquired skills enabled them to take time to negotiate with local staff and residents. First, they established good relationships with the local people, and then mobilized them for the smooth execution of projects. An issue still to be addressed, however, is the performance of a large number of people in a limited time.

\subsubsection{Assistance Organization B}

Assistance Organization B donated toilets and trash boxes to schools and provided materials for hygiene education. The assistance organizations that reconstructed collapsed school buildings usually rebuilt only classrooms; other facilities including toilets were installed after the completion of the school buildings. Assistance Organization B donated toilet facilities when school buildings were reconstructed so that hygienic education could be effectively conducted at school.

Assistance Organization B was based in Japan, but it had no Japanese staff at their project sites in West Sumatra. The international staff was non-Japanese. They were employed by headquarters and sent to Indonesia, whereas the local staff members were Indonesian volunteers who had substantial experience in providing humanitarian assistance at disaster and conflict sites in Indonesia. In Assistance Organization B, local staff members proactively conducted assistance activities under the supervision of the international staff.

\subsubsection{Assistance Organization C}

Assistance Organization C provided technical guidance for earthquake-resistant buildings with the cooperation of a local staff member that they met in Yogyakarta for the relief activities of the Java earthquake in 2006. In the workshop, a Japanese lecturer gave a talk on earthquakeresistant technologies, and an Indonesian lecturer explained the details. A combination of Japanese and Indonesian lecturers enabled Japanese earthquake-resistant technologies to be transferred to Indonesia to suit the local communities.

\subsubsection{Assistance Organization D}

Assistance Organization D constructed halls, which served as offices for the heads of the branch villages, and Assistance Organization D provided the materials required to make these village halls functional.

Assistance Organization D introduced the design and construction of village halls, which were intended to demonstrate Japanese building technologies. However, once the village halls were handed over to the local residents, the residents started to use the hall in many other ways. Halls were used as information booths, and some halls were changed into coffee shops.

Transforming the village halls into coffee shops could be perceived as an economic pursuit; however, in the West Sumatran culture, coffee shops function as places for the exchange of information. By tacitly approving the modification of the use of the village halls, Assistance Organization D responded ingenuously to the high social flux.

\subsection{Domestic Volunteers as Coordinators for Tech- nology Transfer}

Domestic volunteers who participated in the assistance project conducted by Japanese assistance organizations played the role of "translating" knowledge and technologies into forms that are locally acceptable and understandable.

The role of domestic volunteers in Indonesia emerged after the Indian Ocean tsunami in 2004. International humanitarian assistance organizations required local NGOs to serve as their counterparts in providing emergency humanitarian assistance. Volunteers who had participated in the projects of foreign NGOs (in conflict areas such as East Timor and disaster-affected areas such as Aceh) were supposed to share and accumulate the acquired knowledge and skills. These could then be used for projects in other areas of disaster or conflicts. Thus, the domestic volunteers became mediators in the transfer of knowledge and technology.

\section{Transmission of Information in High-Flux Societies}

Disaster victims experience sudden and drastic changes in their worldview. They need information on what, how, and why such incidents are caused. People who have not suffered direct damages also require information to grasp the extent and scale of the disaster for the rescue and reconstruction of victims.

This section describes practices used to transmit and share information on the Java (Bantul) earthquakes of May 2006. ${ }^{27}$ We interviewed the personnel of three NGOs in Yogyakarta city and Bantul district in August 2008.

Bantul district in the Yogyakarta province suffered the heaviest damage, whereas Yogyakarta city, which is the provincial capital and an important urban area in the Yogyakarta province, suffered only slight damage. Three local NGOs based in Yogyakarta city issued community papers in an attempt to transmit and share information on the damage caused and the rescue and reconstruction operations.

\subsection{Disaster-Affected Society in Java}

The Yogyakarta province and parts of the Central Java province, located within a radius of $50 \mathrm{~km}$ of the epicen-

27. Refer to the discussions in Reference [32]. 
ter, were devastated. The death toll was over 5,000 in the Java earthquake. Two rural districts, Bantul district in the Yogyakarta province and Klaten district in the Central Java province, suffered the heaviest damages.

Yogyakarta city is a premier international tourist city in Java; it has world heritage monuments such as the Borobudur ruins and Prambanan temples. Yogyakarata city is also known as an educational city with prestigious universities such as Gajah Mada University. The city has a royal palace where the sultan assumes the hereditary governorship of the Yogyakarta province and functions similar to an elected administrative chief. Yogyakarta city functions as the center of Javanese culture, which is symbolized by traditional interpersonal relationships.

In the densely populated rural areas around Yogyakarta city, local communities organize rumah tetangga (RT) or neighborhood associations to provide substantial mutual aid. They are also closely linked with extra-regional areas of Yogyakarta city (within commuting distance) and Jakarta, the metropolis in Java Island (where mutual-aid societies of compatriots are organized). The men also go overseas for jobs.

For the Javanese in hinterland rural areas, Yogyakarta city serves as the center of Javanese culture and the contact point for extra-regional areas.

\subsection{Natural Disasters and Information}

Information is one of the most important requirements at disaster sites; however, increasing the information output alone would not be enough. It is also important to ensure the authenticity of information, which is secured by its sources and communication routes. Because the Indian Ocean tsunami was still vivid in the minds of the people, some residents evacuated to the hills after the Java earthquake of 2006 to protect themselves from any future tsunamis. Some persons tried to evacuate from the base of the mountain to the coastal areas in the belief that the earthquake was caused by the eruption of Mount Merapi in the suburbs of the Yogyakarta province. Therefore, traffic snarls occurred at the intersection of bidirectional vehicular movement.

People in the disaster sites had difficulty collecting information for about a week after the Bantul earthquake. It was not customary to subscribe to newspapers. Newspapers were mainly subscribed by the residents of Yogyakarta city. In the suburban areas, newspapers were posted on the bulletin boards of mosques or sold on the streets. For the daily news, people usually tune in to the TV or the radio. However, TV broadcasting services were unavailable for ten days after the earthquake because of power failure. People could receive radio broadcasts via battery-operated radio sets; however, this facility was limited because there was a steep hike in battery prices. Hence, for some period after the earthquake, they received indirect information mainly from either market billboards or people who received handbills from NGOs.

\subsection{Local NGOs and Transmission of Information}

Local NGOs based in Yogyakarta city published community papers in an effort to share information with the rural disaster sites. Such community papers are Saksi Gempa (Witness of Earthquakes), Suara Korban Bencana (Voices of Disaster Victims), and Merti Jogja (Guardian of Jogjakarta).

Local NGOs issued community papers because "national newspapers mainly carry the views of politicians or government officials at Jakarta and little space is provided for the voices of public including disaster victims." 28 Community papers were intended to connect assistance givers and disaster victims besides helping disaster victims connect among themselves. These papers were prepared for publication for three months; subsequent publications were to depend on the need for such papers and the availability of funds.

\subsubsection{Saksi Gempa (Witness of Earthquakes)}

Saksi Gempa or Witness of Earthquakes was published by a local NGO named Combine that specialized in information management. Before the earthquake struck the area, Combine had launched a website called Merapi $\mathrm{Net}^{29}$ to post short messages on the web bulletin board by using mobile phones in preparation for the possible eruptions of Mount Merapi. In the wake of the earthquake, they launched a website Saksi Gempa ${ }^{30}$ to provide information on damages and rehabilitation assistance, such as the prices of building materials. Combine published a community paper titled Saksi Gempa to convey the situation of disaster sites to the government organizations and domestic and international NGOs.

Saksi Gempa, which was started on June 3, 2006, was published twice a week on four A5-size sheets of paper. This practice was followed for the first month from the first issue to the seventh issue. From the eighth issue onward, it was published three times a week on four A4-size pages. About 1,500 copies were printed, 300 to 500 copies of which were distributed through NGOs. The community paper was also available from the Saksi Gempa website.

The paper reported the details regarding the persons and organizations that were involved in different kinds of rescue operations. In response to the needs of disaster victims received as short messages sent from mobile phones, the paper carried articles on how disaster victims could take loans from banks." Saksi Gempa drew some complaints from NGOs when it published a list of mobile numbers of the persons in charge of local and international NGOs. However, the paper justified its position by arguing that posting the list would enhance transparency of the NGO activities.

The publishers of Saksi Gempa said, "Foreign NGOs are reliable as long as they understand the Javanese culture through their past activities in Java. For other NGOs,

28. From the interview with Mr. Prim Nugroho on August 16, 2006.

29. Retrieved from http://merapi.combine.or.id/ on July 31, 2011.

30. Retrieved from http://www.saksigempa.org/ on October 15, 2009. 


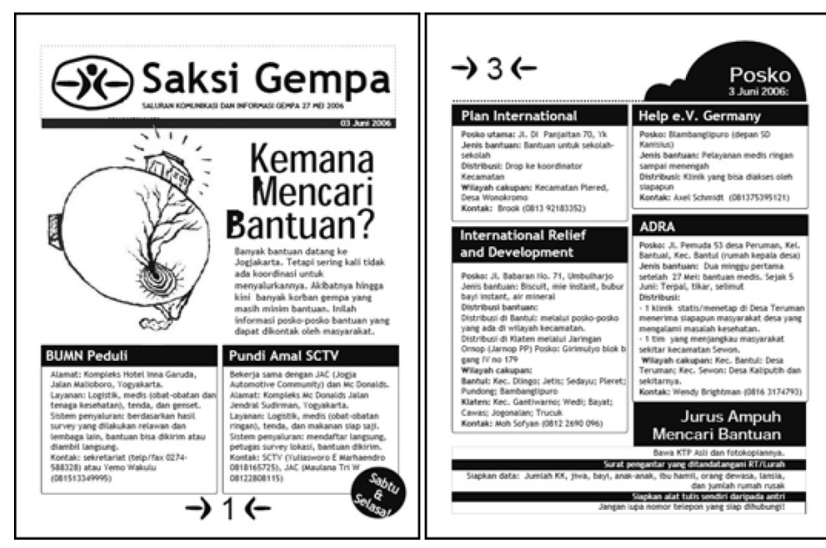

Fig. 1. Pages 1 and 3 of the first issue of Saksi Gempa.

we cannot say that they should not conduct assistance projects here, but we have to report their activities in our papers to enhance transparency as well as to inform people of their reliability." The paper also specified that extraregional NGOs should not rush into relief activities; instead, they should open local offices first and commence their assistance activities only after they have fully understood the Javanese society and culture.

\subsubsection{Suara Korban Bencana (Voices of Disaster Vic- tims)}

Twenty-six local NGOs developed the forum of Suara Korban Bencana on May 29, 2006. Key participants of the forum were Cindelaras, Combine, and Institute for Research and Empowerment (IRE). By August 2006, the number of participating NGOs grew to 69 organizations. The forum first published the community paper Suara Korban Bencana (Voices of Disaster Victims) on June 20, 2006. The paper was published weekly on eight A4-size pages. Ten thousand copies were circulated through participating NGOs, mobile clinic services, and street gasoline stands. The paper was also available on the website of the forum. 31

The editorial policy of Suara Korban Bencana was that any views or opinions that would encourage disaster victims should be given priority over governmental statements or voices of NGOs. Heartening news included incidents about victims who performed small acts of mercy - farmers who resumed farming soon after the earthquake even though their houses had completely collapsed; bamboo merchants who carried on business at unchanged prices even with increasing demand for bamboo; and disaster victims sharing their sparse resources with other disaster victims. The paper also carried cartoons for increasing its acceptability among readers. The paper clarified its publication preferences in colophons that stated, "the editors will cordially welcome short messages, articles, photographs, pictures, data, and any other forms of information concerning the earthquake disaster victims, but not instant noodles."

31. Retrieved from http://www.suarakorbanbencana.org/ on October 15, 2009.

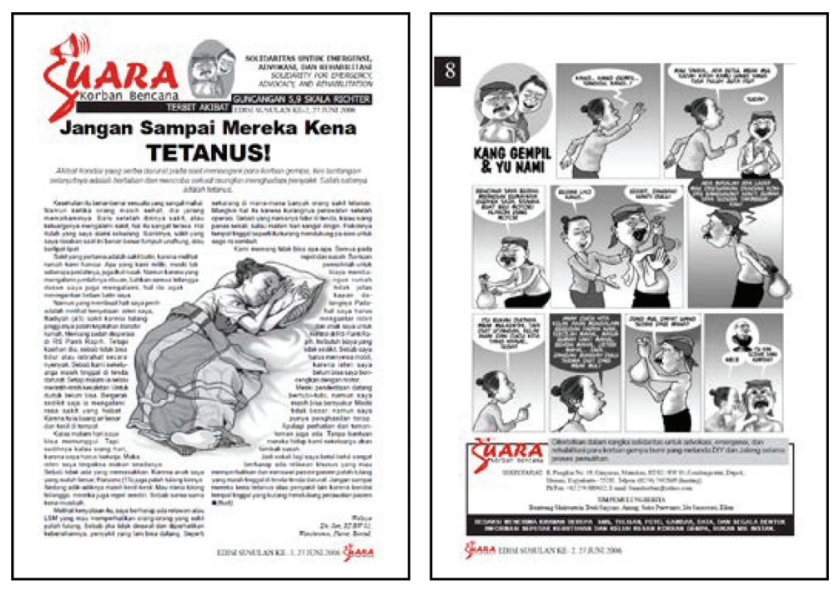

Fig. 2. Pages 1 and 8 of No. 2 issue of Suara Korban Bencana.

\subsubsection{Merti Jogja (Guardian of Jogjakarta)}

Local NGO activists organized a forum in the first week of June 2006 and published a community paper Merti Jogja (Guardian of Jogjakarta) on the earthquake and relief operations on June 23, 2006. The paper did not carry any advertisements and was distributed free of cost. Two thousand copies of this eight-page paper were first published weekly on A3-size pages. Subsequently, 1,000 copies were published biweekly.

The editors were Mr. Prim Nugroho and the staff of Humana, a local NGO that used Prim Nugroho's house as their office. The paper was distributed to readers through related NGOs. The paper used a large typeface to ensure easy readability when pasted on walls.

Merti Jogja was designed to be read by farmers in Javanese villages. The paper contained pictures of characters in wayang or puppet shadow plays that are popular in Javanese villages. It contained the autography of former Indonesian President Sukarno and photographs of the former sultan of Yogyakarta. It also provided children's "illustrated diaries" and "what if I am ..." columns to encourage readers to contribute to the paper. Many Javanese words were inserted within the Indonesian text because people felt more comfortable with the Javanese language than the national Indonesian language.

Local NGOs based in Yogyakarta city organized forums and published community papers to share information with the disaster victims in the heavily devastated suburban rural areas. Such activities were launched because relief activities on the national level or by foreign organizations did not always meet the expectations of local residents. Additionally, the existing national media was not always able to satisfactorily report local events.

\subsection{Community Papers as Information Intermedi- aries}

In responding to disasters, central governments and international humanitarian assistance organizations worked out programs for relief and reconstruction operations based on their understanding of the disaster. Meanwhile, 
the disaster-affected people tried to deal with the reconstruction operations based on their own perceptions of reality. As a result, some residents in the disaster sites came up as intermediaries to modify the information received from the central government and external societies to suit the conditions of the disaster-affected people.

Because the practice of assisting disaster victims is increasing in popularity worldwide, disaster-affected communities are being directly exposed to assistance activities by international agencies. Local NGOs based in Yogyakarta city also tried to establish grassroots-level contacts to manage local reconstruction activities.

Local NGOs, which published community papers, attempted to modify the information received from the Central Government and international humanitarian assistance organizations to suit the realities of disaster sites before transmitting them to local communities. In societies with high social flux, however, information "translated" by local NGOs does not always conform to the realities of disaster sites. In that sense, community papers will need to further investigate how such transmitted information is accepted and utilized. This will be taken up in our future research study.

\section{Conclusion: Indonesian Model for Disaster Management and Reconstruction}

From the new perspective of social flux, we reviewed how information and technology are transmitted and shared for disaster management and humanitarian assistance in Indonesia. Taking the new aspect of social flux positively, we argued that poskos, domestic volunteers, community papers, and other ingenuous methods were effectively used in distributing relief goods and sharing information. This positive evaluation of the Indonesian way of responding to natural disasters may be validated by assuming that the knowledge and experiences of one social circle need not necessarily be acceptable in other circles.

Proposing specific measures for disaster management and reconstruction are beyond the scope of this paper. However, the concept of high social flux and the ingenuous methods of transferring knowledge and experiences in high-flux societies present a new perspective for disaster management, humanitarian support, and reconstruction activities. This would prove useful for disaster management and reconstruction measures in Indonesia and other countries, especially along the coast of the Indian Ocean, where the social structure is similar to that of Indonesia. ${ }^{32}$

32. Reference [33] refers to the reexamination based on the high mobility of housings in response to disasters in Japanese society.
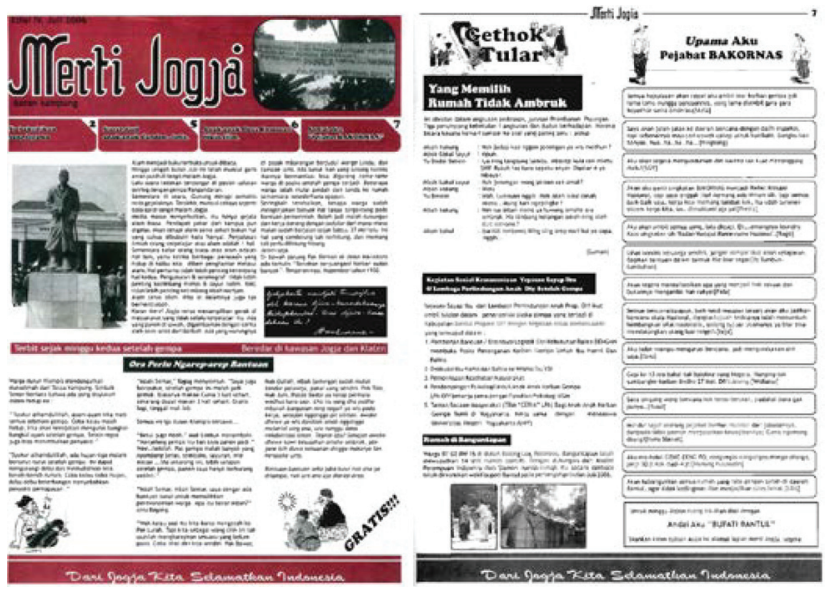

Fig. 3. Pages 1 and 7 of No. 4 issue of Merti Jogja.

\section{References:}

[1] 山本博之 $2011 「$ 災害と地域研究: 流動化する世界における新 たなつながりを求めて」『地域研究』、11(2)、pp.6-13。

[2] 大矢根淳 · 浦野正樹・田中淳・吉井博明編 2007 『災害社会学入 門』シリーズ「災害と社会」1、弘文堂。

[3] 宮瀧交二 2010 「環境史・災害史研究と考古学」水島司編『環境 と歴史学一歴史研究の新地平』アジア遊学 136、勉誠出版、 pp.46-54。

[4] 岩崎信彦・林勲男ほか編 2008『災害とともに生きる文化と教育 一〈大震災〉からの伝言』昭和堂。

[5] 矢守克也 2009 『防災人間科学』東京大学出版会。

[6] 矢守克也・渥美公秀編著 2011『防災・減災の人間科学—いの ちを支える、現場に奇り添う』新曜社。

[7] 林勲男編著 2010『自然災害と復興支援』明石書店。

[8] 清水展 2003『噴火のこだま噴火のこだま——ピナトゥボ・アエ 白被災と新生をめぐる文化・開発・NGO』九州大学出版会。

[9] ホフマン スザンナ・M＆オリヴァー=スミス、アンソニー編 著 (若林佳史訳) 2006 『災害の人類学一スタタトロフィと文 化』明石書店。

[10] 廣井修編著 2004『災害情報と社会心理』北樹出版。

[11] 元田結花 2007『知的実践としての開発援助——アジンン゙の興 亡を超えて』東京大学出版会。

[12] 前川啓治 2000 『開発の人類学一一文化接合から翻訳的適応へ』 新曜社。

[13] 真崎克彦 2010 『支援・発想転換・NGO——国際協力の「裏舞 台」から』新評論。

[14] 坪内良博 1998 『小人口世界の人口誌一一東南アジアの風土と 社会』

[15] B. Bronson, "Exchange at the Upstream and Downstream Ends: Notes toward a Functional Model of the Coastal State in Southeast Asia," Hutterer, Karl L. (ed.), Economic Exchange and Social Interaction in Southeast Asia: Perspectives from Prehistory, History, and Ethnography, Ann Arbor: Center for South and Southeast Asian Studies, University of Michigan, pp. 39-52, 1977.

[16] J. Kathirithamby-Wells, and J. Villiers, Southeast Asian Port and Polity: Rise and Demise, Singapore: Singapore University Press, 1990.

[17] 弘末雅士 2004『東南アジアの港市世界——地域社会の形成と世 界秩序』岩波書店。

[18] E. Tagliacozzo, Secret Trades, Porous Borders: Smuggling and States Along a Southeast Asian Frontier, 1865-1915, New Haven: Yale University Press, 2008.

[19] N. Mochtar, Merantau: Causes and Effects of Minangkabau Voluntary Migration (ISEAS Occasional Paper No.5), Singapore: Institute of Southeast Asian Studies, 1971.

[20] ムハマッド・ラジャブ (加藤剛訳) 1983『スマトラの村の思い 出』めこん。

[21] M. Mirwanto, Mengenal dan Memahami Transmigrasi, Jakarta: Pustaka Sinar Harapan [To Know and to Understand Transmigration], 2004.

[22] P. Levang, (Translated by Sri Ambar Wahyuni Prayoga), Ayo ke Tanah Sabrang: Transmigrasi di Inodnesia, Jakarta: Kepustakaan Populer Gramedia [La terre d'en face - La transmigration en Indonesie, Paris: Editions de l'Orstom, 1997], 2003.

[23] L. Suryadinata, et al., Indonesia's Population: Ethnicity and Religion in a Changing Political Landscape, Singapore: Institute of Southeast Asian Studies, 2003. 
Nishi, Y. and Yamamoto, $\mathrm{H}$.

[24] 山本博之2010「転用・改築に強い耐震技術を：インドネシアが 日本の防災に期待するもの」『建築雑誌』日本建築学会、vol.125. No.1604、pp.38-39。

[25] 西芳実 2008「インド洋津波はアチェに何をもたらすのが囲 い込み」を解くためのさまざまな繋がり方」小西正捷他著『イ ンド洋海域世界一人と王ノの移動自然と文化光してことば。 第 4 号、言叢社。

[26] 西芳実 2011 「災害からの復興と紛争からの復興 : 2004 年スマ 卜ラ沖地震・津波の経験から」『地域研究』、第 11 巻第 2 号、 pp.92-105。

[27] 山本博之 $2010 「 人$ 道支援活動とコミュニティの形成」林勲男編 著『自然災害と復興支援』明石書店、pp.361-382。

[28］西芳実・山本博之 2010 「流動性の高い社会における復興 : 2009 年西スマトラ地震における日本の人道支援の事例から考える」 『日本災害復興学会 2010 神戶大会論文集』, pp.93-96。

[29] 山本博之・西芳実編 2010 『学術研究と人道支援—-2009 年西 スマトラ地震て壞れたもの・つくられるもの』京都大学地域研 究統合情報センター。

[30] 山本博之編 2010 『支援の現場と研究をつなぐ—— 2009 年西ス マトラ地震におけるジェンダーコミュニティ、情報』大阪大 学大学院人間科学研究科「共生人道支援研究班」。

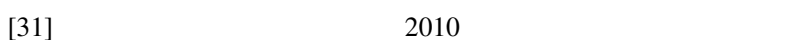
部パダン沖地震被災者支援報告書』ジャパン・プラットフォーム。

[32] 西芳実・山本博之2009「災害対応を通じたコミュニティ再編の 可能性 : 2006 年ジャワ島中部地震におけるコミュニティ・ペー パー発行の事例から」曰日本災害復興学会 2009 長岡大会論文 集』、pp.67-70

[33] 牧紀男 2011 『災害の住宅誌一一人々の移動とすまい』鹿島出 版会。

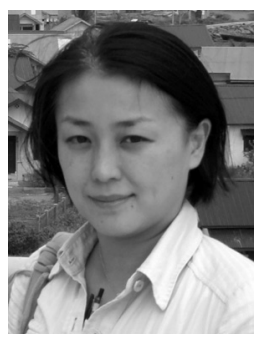

Name:

Yoshimi Nishi

\section{Affiliation:}

Associate Professor, Center for Integrated Area

Studies, Kyoto University

\section{Address:}

Sakyo-ku, Shimoadachimachi 46, Kyoto-shi, Kyoto 606-8501, Japan Brief Career:

2007 Research Associate, Human Security Program, Graduate School of Arts and Scientists, the University of Tokyo

2010 Research Associate, the Asian Institute for Intellectual Collaboration, Rikkyo University

2011 Associate Professor, Center for Integrated Area Studies, Kyoto University

\section{Selected Publications:}

- "Rehabilitation and Reconstruction after Armed Conflict and Natural Disaster: in the case of Sumateran Earthquake and Tsunami in 2004," Journal of Area Studies, Vol.11, No.2, pp. 92-105, 2011 (in Japanese).

- "Among Bangsa, Keturunan, and Daerah: Peace-Building and Group Identity in the law on Governing Aceh, 2006," H. Yamamoto, M. Anthony,

M. Kawashima, and K. Arai (eds.), Bangsa and Umma: Development of People-Grouping Concepts in Islamized Southeast Asia, Kyoto University Press, pp. 166-182.

Academic Societies \& Scientific Organizations:

- Japan Society for Southeast Asian Studies (JSSEAS)

Japan Association for Asian Studies (JAAS)

Japan Society for Disaster Recovery and Revitalization
Name:

Hiroyuki Yamamoto

\section{Affiliation:}

Center for Integrated Area Studies, Kyoto University

Address:

Sakyo-ku, Shimoadachimachi 46, Kyoto-shi, Kyoto 606-8501, Japan

Brief Career:

Your History

Selected Publications:

- Your Works

Academic Societies \& Scientific Organizations:

- Your Learned Societies 